\title{
AN EXAMINATION OF THE METHODS OF COPING WITH STRESS USED BY FAMILIES WITH CHILDREN AGED BETWEEN 7 AND 17 AND HAVING DIFFERENT DEVELOPMENTAL CHARACTERISTICS ${ }^{1}$
}

\section{7-17 YAŞ ARASI FARKLI GELIŞSIMSEL ÖZELLİKLERI OLAN ÇOCUKLARA SAHIP AILELERIN STRESLE BAŞA ÇIKMA YÖNTEMLERININ INCELENMESI}

\author{
Ercan ŞAHBUDAK ${ }^{1}$, Ayça GÜRKAN ${ }^{2}$, Mustafa TALAS ${ }^{3}$, Nurullah KARTA ${ }^{4}$, \\ Selvinaz SAÇAN ${ }^{5}$, Kaya YILDIZ ${ }^{6}$, Erdal ŞEN ${ }^{7}$ \\ ${ }^{1}$ Cumhuriyet University, Faculty of Literature, Department of Sociology, Sivas / Turkey \\ ${ }^{2}$ Ege University, Faculty of Nursing, Department of Psychiatric Nursing, Izmir / Turkey \\ ${ }^{3}$ Niğde University, Faculty of Education, Department of School Teaching, Niğde / Turkey
} ${ }^{4}$ Van Yüzüncü Yıl University, Faculty of Education, Department of Secondary Education, Van / Turkey ${ }^{5}$ Adnan Menderes University Söke School of Health Department of Child Development, Aydın / Turkey

${ }^{6}$ Abant Izzet Baysal University, Faculty of Education, Primary Education, Bolu / Turkey

${ }^{7}$ Istanbul Gelişim University, Faculty of Economics, Administrative and Social Sciences, Business Administration (English) Department, Istanbul / Turkey

Öz: Bu araştırma daha önceden güvenirliliği ve geçerliliği sağlanmış bir uygulama çalışmasında kullanılan anket kullanılarak hazırlanmıştır. Araştırma süresi 6 aydır. Araştırma basit rassal yöntem ile gerçekleștirilmiş olup, tüm katılımcılar rast gele seçilmiştir. Türkiye evreni Sivas, İstanbul, İzmir, Adana, Erzurum, Niğde, Bolu, Kastamonu, Ankara, Bursa, Samsun, İzmit, Sakarya, Van ve Bitlis örneklemi şeklinde hazrlanmıştr. Uygulamaya toplam $(\mathrm{N}=1177)$ kişi katılımıştır. Katılımclardan elde edilen veriler SPSS Pasw 18.0 paket programı ile analiz edilmiștir. Analizde betimleyici istatistikler, güvenirlilik analizi, kruskal Wallis, man whitney u, kolmogorov smirnov ve jonckheere-terpstra analizlerinden yararlanılmıştr. Değişkenler arası ilişki farklarında 0.05 önem düzeyi dikkate alınmıştır. Araştırma sonunda katılımcıların büyük çoğunluğunun farklı gelişimsel özelliğe sahip çocuklara sahip ailelerin stresle başa çıkma konusunda sorun yaşadığı, stres yönetimi konusunda ciddi sorunlar ile karşıı karş̧ıa kaldığı belirtilmiștir. Gelişimsel özellikteki çocuklara sahip ailelerin büyük çoğunluğu, bu özelikteki çocuklar nedeniyle toplumsal dıslanma, aile içi sosyal ve kültürel sorunlar, siddet ile kişiler arası ilişkilerde yıpranmaya maruz kaldığı ifade edilmiştir. Sorun yaşayan ailelerin bu özelliğe sahip çocuklarla birlikte rehabilite edildikleri, psikolojik ve sosyolojik açııdan destek aldığı saptanmıştır.

Anahtar Kelimeler: Çocuk, Özellik, Gelişimsel Özellik, Stres, Aile, Anne - Baba, Hiperaktivite, Psikoloji
Abstract: This study was carried out through the use of a questionnaire which had been previously used in a practical study verified for reliability and validity. Duration of the study was 6 months. Simple random sampling method was used for the study; all participants were selected randomly. Target population was Turkey, and the sample included the provinces of Sivas, Istanbul, Izmir, Adana, Erzurum, Niğde, Bolu, Kastamonu, Ankara, Bursa, Samsun, Izmit, Sakarya, Van and Bitlis. A total of 1177 people took part in the practice. The data obtained from the participants were analyzed through the SPSS PASW 18.0 software. Descriptive statistics, reliability analysis, Kruskal-Wallis test, Mann-Whitney U test, Kolmogorov-Smirnov test, and Jonckheere-Terpstra test were used in the analysis. A significance level of 0.05 was set for relations and differences among the variables. The results of the study showed that majority of the families with children having different developmental characteristics experience problems with coping with stress and that they are faced with serious problems in terms of coping with stress. It was reported that vast majority of families that have children with different developmental characteristics are exposed to social exclusion, familial social and cultural problems, violence, and exhaustion in interpersonal relations due to their children's differences. It was found that families with problems are rehabilitated together with their children and get psychological and sociological support.

Key Words: Child, Characteristic, Developmental Characteristic, Stress, Family, Parent, Hyperactivity, Psychology

Doi: $10.17363 /$ SSTB.20151714054

(1) Corresponding Author: Ercan ŞAHBUDAK, Cumhuriyet University, Faculty of Literature, Department of Sociology, Sivas / Turkey sahbudakercan@gmail.com Arrival Date 14.09.2015 Date of Admission: 16.10.2015 Article Type: (Research and Practice) Conflict of Interest No "Ethics Committee Yes"(Cumhuriyet Universitesi, Faculty Dean of Date:07-01-2015 Number:81011618/044/653) 


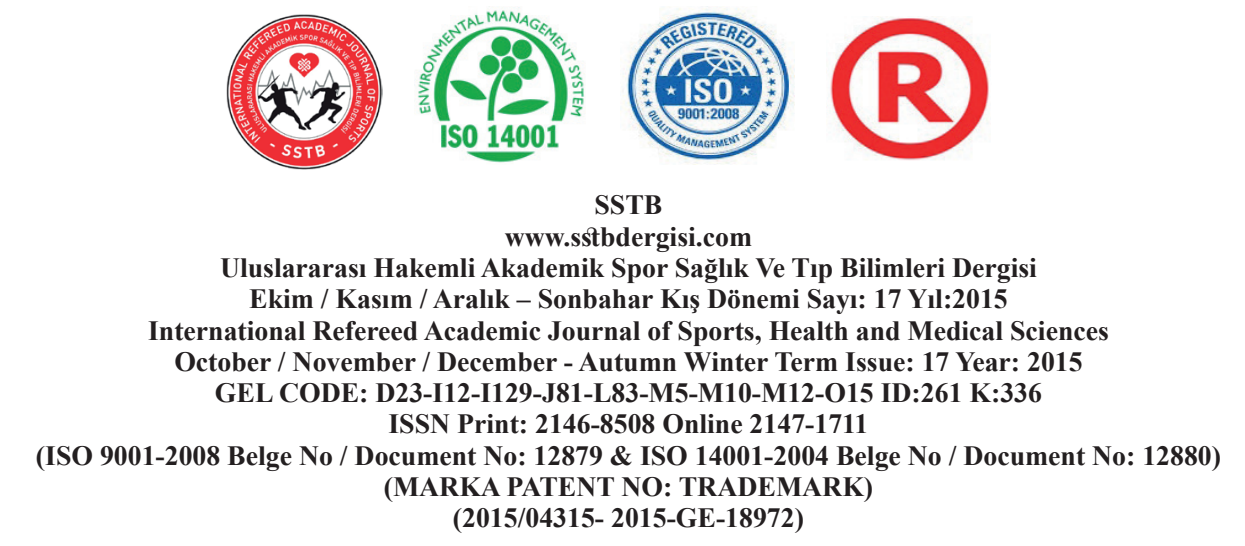

\section{INTRODUCTION}

Individuals and families are the essential building blocks, with individuals forming families and families forming the society. Therefore the concept of family has been accepted in legal, political, social and cultural terms in all societies, and it has been protected and secured in all aspects. And the most important element in the formation of families and continuity of generation is the fundamentals of the concept of child. A sound generation and society require creating a profile of strong, educated, selfsufficient individuals with more permanent and effective sociocultural values. And the physical and psychological healthiness of individuals requires the general structure of the family and the "Genetic and Physiological" gene map to be proper and nonproblematic. The most important indicator of this is the fact that marriages between close relatives are not supported materially or morally. The prohibition or unacceptability of inbreeding for medical reasons is considered necessary for "medical" health of future generations. For inbreeding and close genetic relationships lead to the birth of unhealthy family members and they turn infants into problems in physical and psychological terms. Many studies carried out on this subject have clearly revealed the reality of this issue.

\section{THEORETICAL FRAMEWORK AND LITERATURE REVIEW}

In many societies, the family and its individuals form a model in the creation of large societies.
Therefore, the smallest unit of society is the family. Presence of children is quite important for the realization of the concept of family, for the continuity of its existence, and for the creation of plans for future. In patriarchal societies and families, the child is considered as the assurance of the future of the family (Ataman, 2003). "Marriage is a social and legal form of small group or a social institution with traditional and psychological aspects." has been considered as sacred and legally secured in many societies. Besides, it has been politically supported to expand, grow, and produce social benefit. ${ }^{2}$ Family structure has been treated from different sociological perspectives. The concept of family has been also examined in terms of size, and it has been reported to differ in various aspects. The family size has been divided into two main types based on the majority of the family members and the number of people. These are nuclear family and extended family. While a nuclear family is made up of mother, father and children, the extended type of family includes mother, father, daughters, sons, grandchildren and other family members. Family types have been also diversified based on marriage. These are examined under the titles of Monogamy and Polygamy. A monogamous marriage refers to a

1 http://www.ataturkuni.net/ow_userfiles/plugins/ forum/attachment_2839_54c8-8fda7ba161_54c8f c5e47530_\%C3\%BCnite-5toplumsal-bir-krumolarak-evlilik-ve-aile.pdf

2 http://www.canaktan.org/politika/refah-devleti/ araclar.htm 


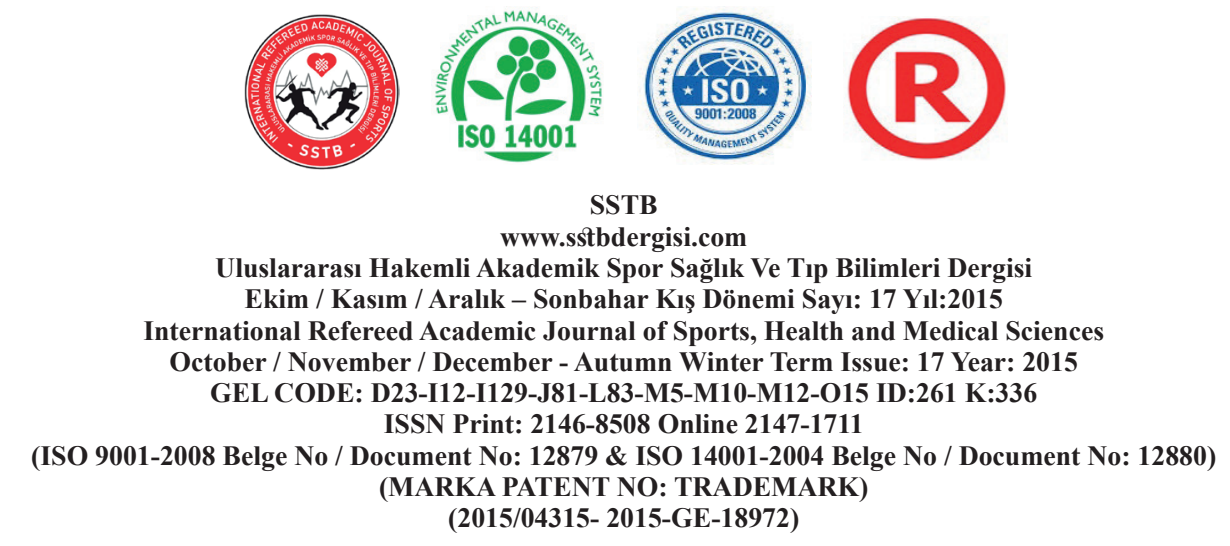

marriage that is established between one man and one woman. Polygamous marriage refers to a type of marriage in which one individual can live with more than one spouse; while it can be sociologically examined, it is con considered as real in legal terms. Generally, polygamous type of marriage is observed in less developed or undeveloped, backward societies. It is quite common in Asian and African countries. Family is also divided into three types based on the type of authority. These are strict family, loose family, and democratic family. When the strict and loose types of family are addressed from psychological, sociological and legal perspectives, there seems to be a lot of problems among the family members. On the other hand, democratic type of family includes warm relationships, supervision, rules and the explicitness of their reasons, mutual trust and discussions of ideas, permission for self-defense, independent behavior, and the right to speak. A consideration of the social events in the future lives of children growing up in democratic families shows that they become skilled, highly confident, sociable, independent, realistic individuals that establish warm relationships with their social circles and are consistent in their behavior. ${ }^{3}$ The social, psychological, material and cultural relations among the individual members of the family constitute the body of values that contribute to the shaping of the future structure of the family and

3 https://www.academia.edu/5811043/ A $\%$ C $4 \%$ B0LE_NED $\%$ C4\%B0R_A $\%$ C $4 \%$ B $0 L E \_$ $\% \mathrm{C} 3 \% 87 \mathrm{E} \% \mathrm{C} 5 \% 9 \mathrm{E} \% \mathrm{C} 4 \% \mathrm{~B} 0 \mathrm{TLER} \% \mathrm{C} 4 \% \mathrm{~B} 0$ to its continuity. The expectations, bringing-up, health, and physical and psychological conditions of the family members, especially of the children, are important for parents. For the family is the initial step where the bringing-up and education of the child begin. ${ }^{4}$ Any physical or psychological problems, which the child members of a family may have, cause the other members of the family, especially the parents, to live an arduous life (Bilal et al., 2005). One of the familial situations that are the most difficult to get used to and to accept is when a member of the family is troubled or physically or psychologically different. Such situations cause other individuals in the family to experience various problems, especially stress, and they lead to conflict, abandonment or exclusion (Akcakın and Erdem, 2001). Education is the leading problem that the families with disabled children have (Akydoğan et al., 1999). Inability to meet economic needs in some cases lead parents to such feelings as deficiency, inadequacy, and most importantly, self-accusation (Küçüker, 2001). Conflicts and even divorces can be observed among the spouses that have disabled children with different characteristics (Kavak, 2007). In families with a disabled child, the attitudes and behavior of the child with disabilities towards the other members of the family change when his/her needs or demands are not fulfilled (Özsoy, 1998). The stress resulting from the disabled child causes psychological problems between spouses, and the

\footnotetext{
4 http://tegm.meb.gov.tr/dosya/okuloncesi/036ebaderegitimcikitap.pdf
} 


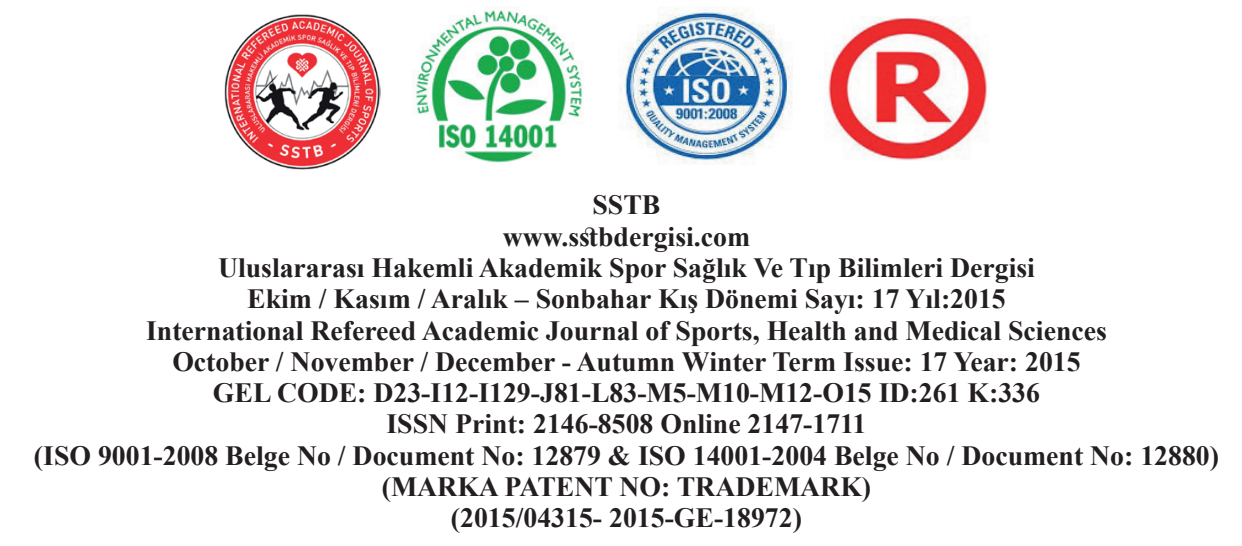

increase of the stress level may eventually lead to mutual accusations. This situation may cause the spouses to exclude each other and divorce or even to isolate the disabled child from the family (Lusting, 1999).

\section{Purpose, Scope and Method}

This study aims to answer the question whether the psychological wellbeing and methods of coping with stress used by families with children aged between 7 and 17 and having special needs (diagnosed with Mental deficiency / Pervasive developmental disorder / Physical deficiency) vary by such variables as the age of the child, type of disability, gender of the parent, and educational level. The first part of the questionnaire includes the demographic and descriptive characteristics of the participants and their children, and the second part includes the coping methods of the parents. Descriptive statistics were used for the analysis of the collected data, and various tests were used for the determination of the differences by certain variables in the methods of the parents for coping with the stress. The measuring tool used in this research is the questionnaire form that had been previously used in the study of Korkmaz et al. titled "Analysis of the Methods of Managing Stress Used by the Families Having Children with Different Developmental Characteristics for 7-17 Age Group" published in ACED International Journal of Family, Child and Education, August - December Issue: 04, Volume: 02 pp.16-50. 872 participants took part in the study carried out by
Korkmaz et al., and the data acquired from these participants were analyzed through the SPSS 18 software. The analysis yielded a Cronbach's Alpha coefficient of 0.982 . The present study included 305 more participants than the previous study did. The target population of the study is Turkey, and the sample includes participants from the provinces of Sivas, Istanbul, Izmir, Adana, Erzurum, Niğde, Bolu, Kastamonu, Ankara, Bursa, Samsun, Izmit, Sakarya, Van and Bitlis. The duration of the study is approximately 6 months. Within this period, expert opinions were taken, and the questionnaires were submitted to the participants by hand, e-mail or mail, or they were interviewed face-to-face. Participants were not asked to provide their official identity information, and no such information was included in the study. All the participants were selected through simple random sampling method. Individuals who took part in the study are primarily composed of persons who have stress and stress-based insufficiency of developmental characteristics or need rehabilitation, as well as their parents. Prior to the research, an official permission was received from the Deanery of the Faculty of Letters of Cumhuriyet University. Similarly, for the use of the previously-used questionnaire in this present study, another permission was received through e-mail from Murat KORKMAZ on 11 January 2015, and then the forms were prepared.

\section{Data Analysis}

Descriptive statistics, reliability analysis, KruskalWallis test, Mann-Whitney U test, Kolmogorov- 


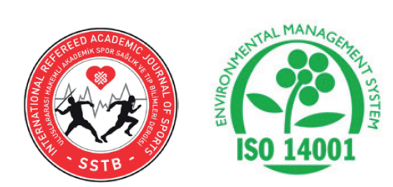

SSTB

www.sstbdergisi.com

Uluslararası Hakemli Akademik Spor Sağlık Ve Tıp Bilimleri Dergisi

Ekim / Kasım / Aralık - Sonbahar Kıș Dönemi Sayı: 17 Yıl:2015

International Refereed Academic Journal of Sports, Health and Medical Sciences

October / November / December - Autumn Winter Term Issue: 17 Year: 2015

GEL CODE: D23-I12-I129-J81-L83-M5-M10-M12-O15 ID:261 K:336

ISSN Print: 2146-8508 Online 2147-1711

(ISO 9001-2008 Belge No / Document No: 12879 \& ISO 14001-2004 Belge No / Document No: 12880)

(MARKA PATENT NO: TRADEMARK)

(2015/04315- 2015-GE-18972)

Smirnov test, and Jonckheere-Terpstra test were used in the analysis. The data obtained in the research were analyzed through the SPSS PASW 18.0 software. A significance level of 0.05 was set for relations and differences among the variables.

\section{Research Hypotheses}

- H1: Do the psychological wellbeing and strategies of coping with stress of parents having children with special needs vary by the age of the child?

- H2: Do the psychological wellbeing and strategies of coping with stress of parents having children with special needs vary by the gender of the child?

- H3: Do the psychological wellbeing and strategies of coping with stress of parents having children with special needs vary by the child's type of disability?

- H4: Do the psychological wellbeing and strategies of coping with stress of parents having children with special needs vary by the gender of the parent (mother or father)?
- H5: Do the psychological wellbeing and strategies of coping with stress of parents having children with special needs vary by the age of parents?

- H6: Do the psychological wellbeing and strategies of coping with stress of parents having children with special needs vary by the education level of the parents (by the educational statuses of the mother and father)?

- H7: Do the psychological wellbeing and strategies of coping with stress of parents having children with special needs vary by the socioeconomic level of the parents?

IMPLEMENTATION AND ANALYSES

\section{Reliability Analysis}

Table 1. Reliability Analysis for the Scale

\begin{tabular}{|r|r|}
\hline Cronbach's Alpha & Number of items \\
\hline .987 & 123 \\
\hline
\end{tabular}

Since the reliability analysis yielded the result of Alpha $=0.987$, it can be suggested that the 123 items have a very high level of reliability. 
www.sstbdergisi.com

Uluslararası Hakemli Akademik Spor Sağlık Ve Tıp Bilimleri Dergisi

Ekim / Kasım / Aralık - Sonbahar Kıș Dönemi Sayı: 17 Yıl:2015

International Refereed Academic Journal of Sports, Health and Medical Sciences

October / November / December - Autumn Winter Term Issue: 17 Year: 2015

GEL CODE: D23-I12-I129-J81-L83-M5-M10-M12-O15 ID:261 K:336

ISSN Print: 2146-8508 Online 2147-1711

(ISO 9001-2008 Belge No / Document No: 12879 \& ISO 14001-2004 Belge No / Document No: 12880)

(MARKA PATENT NO: TRADEMARK)

(2015/04315- 2015-GE-18972)

\section{DEMOGRAPHIC STATISTICS}

Table 2. Demographic Statistics of the Participants' Parents

\begin{tabular}{|c|c|c|c|}
\hline & & Frequency & Column N \% \\
\hline \multirow[t]{2}{*}{ Your gender } & Female & 776 & $66 \%$ \\
\hline & Male & 401 & $34 \%$ \\
\hline \multirow[t]{4}{*}{ Age group } & 30 or below & 93 & $8 \%$ \\
\hline & $31-40$ & 513 & $44 \%$ \\
\hline & $41-50$ & 443 & $38 \%$ \\
\hline & 51 or above & 128 & $11 \%$ \\
\hline \multirow[t]{6}{*}{ Your educational status } & Literate & 66 & $6 \%$ \\
\hline & Primary school & 315 & $27 \%$ \\
\hline & Middle school & 177 & $15 \%$ \\
\hline & High school & 289 & $25 \%$ \\
\hline & University graduate & 311 & $26 \%$ \\
\hline & $\begin{array}{l}\text { Master's degree or } \\
\text { above }\end{array}$ & 20 & $2 \%$ \\
\hline \multirow[t]{2}{*}{ Do you live with your spouse? } & Yes & 1096 & $93 \%$ \\
\hline & No & 81 & $7 \%$ \\
\hline \multirow[t]{2}{*}{ We, as the mother and father, both work } & Yes & 483 & $41 \%$ \\
\hline & No & 694 & $59 \%$ \\
\hline \multirow[t]{6}{*}{ Your monthly income } & Less than $1000 \mathrm{TRY}$ & 247 & $21 \%$ \\
\hline & 1000-1500 TRY & 234 & $20 \%$ \\
\hline & 1501-2000 TRY & 220 & $19 \%$ \\
\hline & 2001-3000 TRY & 240 & $20 \%$ \\
\hline & 3001-4000 TRY & 104 & $9 \%$ \\
\hline & $4000+$ & 132 & $11 \%$ \\
\hline \multirow{2}{*}{$\begin{array}{l}\text { IS THERE ANYBODY ELSE IN THE FAMILY } \\
\text { (OTHER THAN THE PARENTS) THAT ASSISTS } \\
\text { IN LOOKING AFTER YOUR CHILD? }\end{array}$} & Yes & 386 & $33 \%$ \\
\hline & No & 791 & $67 \%$ \\
\hline \multirow{4}{*}{$\begin{array}{l}\text { WHO ARE THE PEOPLE THAT HELP YOU IN } \\
\text { LOOKING AFTER YOUR CHILD? }\end{array}$} & My mother & 329 & $85 \%$ \\
\hline & My father & 14 & $3 \%$ \\
\hline & My sibling & 7 & $2 \%$ \\
\hline & Caretaker & 36 & $9 \%$ \\
\hline
\end{tabular}


SSTB

www.sstbdergisi.com

Uluslararası Hakemli Akademik Spor Sağlık Ve Tıp Bilimleri Dergisi

Ekim / Kasım / Aralık - Sonbahar Kıș Dönemi Sayı: 17 Yıl:2015

International Refereed Academic Journal of Sports, Health and Medical Science

October / November / December - Autumn Winter Term Issue: 17 Year: 2015

GEL CODE: D23-I12-I129-J81-L83-M5-M10-M12-O15 ID:261 K:336

ISSN Print: 2146-8508 Online 2147-1711

(ISO 9001-2008 Belge No / Document No: 12879 \& ISO 14001-2004 Belge No / Document No: 12880)

(MARKA PATENT NO: TRADEMARK)

(2015/04315- 2015-GE-18972)

Table 3. Demographic Statistics of the Participants

\begin{tabular}{|c|c|c|c|}
\hline & & Frequency & Column N \% \\
\hline \multirow[t]{3}{*}{ Age group of the child } & $7-9$ & 325 & $28 \%$ \\
\hline & $10-12$ & 333 & $28 \%$ \\
\hline & $13-17$ & 518 & $44 \%$ \\
\hline \multirow[t]{2}{*}{ Gender of your child } & Female & 498 & $42 \%$ \\
\hline & Male & 679 & $58 \%$ \\
\hline \multirow[t]{5}{*}{ The school that your child attends } & 1.00 & 392 & $33 \%$ \\
\hline & 2.00 & 173 & $15 \%$ \\
\hline & 3.00 & 192 & $16 \%$ \\
\hline & 4.00 & 147 & $13 \%$ \\
\hline & 5.00 & 274 & $23 \%$ \\
\hline \multirow{2}{*}{$\begin{array}{l}\text { YOU'RE YOUR CHILD HAVE } \\
\text { A MENTAL OR PHYSICAL } \\
\text { DISABILITY }\end{array}$} & Yes & 585 & $50 \%$ \\
\hline & No & 593 & $50 \%$ \\
\hline \multirow[t]{3}{*}{ Diagnosis of your child } & Mental disability & 269 & $45 \%$ \\
\hline & Visual impairment & 239 & $40 \%$ \\
\hline & Hearing impairment & 84 & $14 \%$ \\
\hline \multirow{4}{*}{$\begin{array}{l}\text { WHAT IS YOUR CHILD'S LEVEL } \\
\text { OF DEFICIENCY }\end{array}$} & Very severe & 32 & $5 \%$ \\
\hline & Severe & 207 & $35 \%$ \\
\hline & Medium & 209 & $35 \%$ \\
\hline & Mild & 143 & $24 \%$ \\
\hline \multirow{2}{*}{$\begin{array}{l}\text { DOES YOUR CHILD ATTEND } \\
\text { A SPECIAL EDUCATION } \\
\text { INSTITUTION? }\end{array}$} & Yes & 485 & $82 \%$ \\
\hline & No & 107 & $18 \%$ \\
\hline
\end{tabular}


www.sstbdergisi.com

Uluslararası Hakemli Akademik Spor Sağlık Ve Tıp Bilimleri Dergisi

Ekim / Kasım / Aralık - Sonbahar Kıș Dönemi Sayı: 17 Yıl:2015

International Refereed Academic Journal of Sports, Health and Medical Sciences

October / November / December - Autumn Winter Term Issue: 17 Year: 2015

GEL CODE: D23-I12-I129-J81-L83-M5-M10-M12-O15 ID:261 K:336

ISSN Print: 2146-8508 Online 2147-1711

(ISO 9001-2008 Belge No / Document No: 12879 \& ISO 14001-2004 Belge No / Document No: 12880)

(MARKA PATENT NO: TRADEMARK)

(2015/04315- 2015-GE-18972)

\section{ANALYSES}

H1: Do the psychological wellbeing and strategies of coping with stress of parents having children with special needs vary by the age of the child?

An examination of the methods of coping with stress used by the participating parents shows that the items of Problem solving (7-9 age group has the highest average), Social support seeking (10-12 age group has the highest average), Somatization (13-17 age group has the highest average),
Obsessive-compulsive (13-17 age group has the highest average), Interpersonal sensitivity (13-17 age group has the highest average), Hostility (1317 age group has the highest average), Phobic anxiety (7-9 age group has the highest average), Paranoid ideation (10-12 age group has the highest average), Psychoticism (10-12 age group has the highest average), and Additional scale (13-17 age group has the highest average) vary by the age of child.

Table 4. Kruskal-Wallis Test on the Methods of Coping with Stress Used by Parents by the Variable of the Age of Child

\begin{tabular}{|l|r|r|c|}
\hline \multicolumn{4}{|c|}{ Test Statistics ${ }^{\mathbf{a}, \mathbf{b}}$} \\
\hline Problem solving & Chi-square & df & Asymp. Sig. \\
Social support seeking & 15,043 & 2 &, 001 \\
Avoidance & 6,865 & 2 &, 032 \\
Somatization & 1,304 & 2 &, 521 \\
Obsessive-compulsive & 48,625 & 2 &, 000 \\
Interpersonal sensitivity & 6,283 & 2 &, 043 \\
Depression & 9,823 & 2 &, 007 \\
Anxiety & 4,740 & 2 &, 093 \\
Hostility & 5,943 & 2 &, 051 \\
Phobic anxiety & 22,961 & 2 &, 000 \\
Paranoid ideation & 11,254 & 2 &, 004 \\
Psychoticism & 18,702 & 2 &, 000 \\
Additional scale & 11,192 & 2 &, 004 \\
a. Kruskal Wallis Test & 11,322 & 2 &, 003 \\
b. Grouping Variable: Age group of the child & & \\
\hline
\end{tabular}




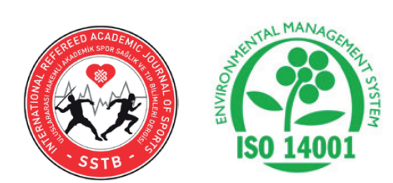

SSTB

www.sstbdergisi.com

Uluslararası Hakemli Akademik Spor Sağlık Ve Tıp Bilimleri Dergisi

Ekim / Kasım / Aralık - Sonbahar Kıș Dönemi Sayı: 17 Yıl:2015

International Refereed Academic Journal of Sports, Health and Medical Sciences

October / November / December - Autumn Winter Term Issue: 17 Year: 2015

GEL CODE: D23-I12-I129-J81-L83-M5-M10-M12-O15 ID:261 K:336

ISSN Print: 2146-8508 Online 2147-1711

(ISO 9001-2008 Belge No / Document No: 12879 \& ISO 14001-2004 Belge No / Document No: 12880)

(MARKA PATENT NO: TRADEMARK)

(2015/04315- 2015-GE-18972)

H2: Do the psychological wellbeing and strategies of coping with stress of parents having children with special needs vary by the gender of the child?

An examination of the methods of coping with stress used by the participating parents by the gender of their children shows that the items of Problem solving (Females have the highest average), Social support seeking (Females have the highest average), Somatization (Males have the highest average), Depression (Females have the highest average), and Hostility (Males have the highest average) are affected by the gender of the child while the others are not affected.

Table 5. Mann-Whitney U Test on the Methods of Coping with Stress Used by Parents by the Variable of the Gender of Child

Test Statistics ${ }^{\mathrm{a}}$

\begin{tabular}{|l|c|c|c|c|}
\hline & Mann-Whitney U & Wilcoxon W & \multicolumn{1}{|c|}{ Z } & Asymp. Sig. (2-tailed) \\
\hline Problem solving & 77765,500 & 204521,500 & $-4,099$ &, 000 \\
Social support seeking & 82306,000 & 209062,000 & $-2,861$ &, 004 \\
Avoidance & 87270,500 & 155535,500 & $-1,509$ &, 131 \\
Somatization & 85559,000 & 153824,000 & $-1,976$ &, 048 \\
Obsessive-compulsive & 92399,000 & 219155,000 &,- 110 &, 912 \\
Interpersonal sensitivity & 87036,000 & 213792,000 & $-1,572$ &, 116 \\
Depression & 81173,500 & 207929,500 & $-3,173$ &, 002 \\
Anxiety & 89424,000 & 216180,000 &,- 921 &, 357 \\
Hostility & 85587,500 & 153852,500 & $-1,972$ &, 049 \\
Phobic anxiety & 90371,000 & 217127,000 &,- 666 &, 505 \\
Paranoid ideation & 90014,500 & 216770,500 &,- 781 &, 435 \\
Psychoticism & 87734,500 & 214490,500 & $-1,386$ &, 166 \\
Additional scale & 91903,000 & 160168,000 &,- 248 &, 804 \\
\hline
\end{tabular}

a. Grouping Variable: Gender of your child

H3: Do the psychological wellbeing and strategies of coping with stress of parents having children with special needs vary by the child's type of disability?
An examination of the methods of coping with stress used by the participating parents by the type of disability shows that the items of Problem solving (visual impairment has the highest average), Social support seeking (hearing impairment has the highest 

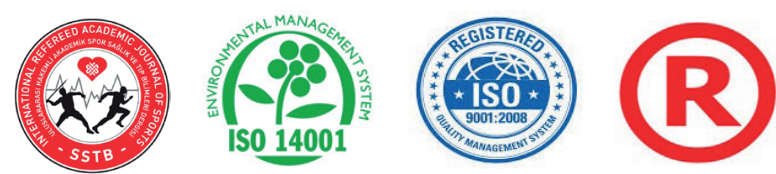

SSTB

www.sstbdergisi.com

Uluslararası Hakemli Akademik Spor Sağlık Ve Tıp Bilimleri Dergisi

Ekim / Kasım / Aralık - Sonbahar Kıș Dönemi Sayı: 17 Yıl:2015

International Refereed Academic Journal of Sports, Health and Medical Sciences

October / November / December - Autumn Winter Term Issue: 17 Year: 2015

GEL CODE: D23-I12-I129-J81-L83-M5-M10-M12-O15 ID:261 K:336

ISSN Print: 2146-8508 Online 2147-1711

(ISO 9001-2008 Belge No / Document No: 12879 \& ISO 14001-2004 Belge No / Document No: 12880)

(MARKA PATENT NO: TRADEMARK)

(2015/04315- 2015-GE-18972)

average), Avoidance (visual impairment has the highest average), Somatization (visual impairment has the highest average), Obsessive-compulsive (mental disability has the highest average), Interpersonal sensitivity (visual impairment has the highest average), Anxiety (visual impairment has the highest average), Phobic anxiety (mental disability has the highest average), and Additional scale (visual impairment has the highest average) are affected by the child's type of disability.

Table 6. Kruskal-Walls Test on the Methods of Coping with Stress Used by Parents by the Variable of the Child's Type of Disability

Test Statistics ${ }^{\mathrm{a}, \mathrm{b}}$

\begin{tabular}{|l|r|r|r|}
\hline & Chi-square & df & Asymp. Sig. \\
\hline Problem solving & 54,389 & 2 &, 000 \\
Social support seeking & 33,411 & 2 &, 000 \\
Avoidance & 8,971 & 2 &, 011 \\
Somatization & 9,086 & 2 &, 011 \\
Obsessive-compulsive & 16,364 & 2 &, 000 \\
Interpersonal sensitivity & 8,038 & 2 &, 018 \\
Depression & 2,781 & 2 &, 249 \\
Anxiety & 7,883 & 2 &, 019 \\
Hostility & 3,697 & 2 &, 158 \\
Phobic anxiety & 13,872 & 2 &, 001 \\
Paranoid ideation & 4,990 & 2 &, 082 \\
Psychoticism & 1,745 & 2 &, 418 \\
Additional scale & 12,793 & 2 &, 002
\end{tabular}

a. Kruskal Wallis Test

b. Grouping Variable: Diagnosis of your child

H4: Do the psychological wellbeing and strategies of coping with stress of parents having children with special needs vary by the gender of the parent (mother or father)?

An examination of the methods of coping with stress used by the participating parents by the gender of the parents shows that the items of Problem solving (female has the highest average), Social support seeking (female has the highest average), Avoidance (female has the highest average), Somatization (female has the highest average), Obsessive-compulsive (female has the 


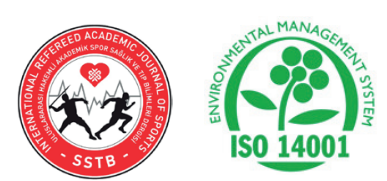

SSTB

www.sstbdergisi.com

Uluslararası Hakemli Akademik Spor Sağlık Ve Tıp Bilimleri Dergisi

Ekim / Kasım / Aralık - Sonbahar Kıș Dönemi Sayı: 17 Yıl:2015

International Refereed Academic Journal of Sports, Health and Medical Sciences

October / November / December - Autumn Winter Term Issue: 17 Year: 2015

GEL CODE: D23-I12-I129-J81-L83-M5-M10-M12-O15 ID:261 K:336

ISSN Print: 2146-8508 Online 2147-1711

(ISO 9001-2008 Belge No / Document No: 12879 \& ISO 14001-2004 Belge No / Document No: 12880)

(MARKA PATENT NO: TRADEMARK)

(2015/04315- 2015-GE-18972)

highest average), Interpersonal sensitivity (female has the highest average), Depression (female has the highest average), Anxiety (female has the highest average), Hostility (female has the highest average), Phobic anxiety (female has the highest average), Paranoid ideation (female has the highest average), Psychoticism (female has the highest average), and Additional scale (female has the highest average) vary by the gender of parent.

Table 7. Kolmogorov-Smirnov Test on the Methods of Coping with Stress Used by Parents by the Variable of the Gender of Parent

Test Statistics ${ }^{\mathrm{a}}$

\begin{tabular}{|l|r|r|r|r|r|}
\hline & \multicolumn{3}{|c|}{ Most Extreme Differences } & $\begin{array}{c}\text { Kolmogorov- } \\
\text { Smirnov Z }\end{array}$ & $\begin{array}{c}\text { Asymp. Sig. } \\
\text { (2-tailed) }\end{array}$ \\
\hline Problem solving &, 100 &, 001 &,- 100 & 1,402 &, 039 \\
Social support &, 349 &, 000 &,- 349 & 4,880 &, 000 \\
seeking &, 165 &, 000 &,- 165 & 2,309 &, 000 \\
Avoidance &, 318 &, 000 &,- 318 & 4,457 &, 000 \\
Somatization &, 244 &, 000 &,- 244 & 3,414 &, 000 \\
Obsessive- &, 272 &, 000 &,- 272 & 3,810 &, 000 \\
compulsive &, 252 &, 000 &,- 252 & 3,533 &, 000 \\
Interpersonal &, 330 &, 000 &,- 330 & 4,615 &, 000 \\
sensitivity &, 383 &, 000 &,- 383 & 5,357 &, 000 \\
Depression &, 130 &, 000 &,- 130 & 1,822 &, 003 \\
Anxiety &, 215 &, 000 &,- 215 & 3,014 &, 000 \\
Hostility &, 208 &, 000 &,- 208 & 2,910 &, 000 \\
Phobic anxiety &, 249 &, 000 &,- 249 & 3,491 &, 000 \\
Paranoid ideation & & & & & \\
Psychoticism & & & & \\
Additional scale & & & & & \\
\hline
\end{tabular}

a. Grouping Variable: Your gender

H5: Do the psychological wellbeing and strategies of coping with stress of parents having children with special needs vary by the age of parents?
An examination of the methods of coping with stress used by the participating parents by the age of parents show that the items of Problem solving (31-40 age group has the highest average), Social 

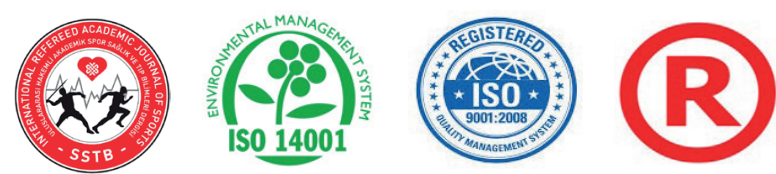

SSTB

www.sstbdergisi.com

Uluslararası Hakemli Akademik Spor Sağlık Ve Tıp Bilimleri Dergisi

Ekim / Kasım / Aralık - Sonbahar Kış Dönemi Sayı: 17 Yıl:2015

International Refereed Academic Journal of Sports, Health and Medical Sciences

October / November / December - Autumn Winter Term Issue: 17 Year: 2015

GEL CODE: D23-I12-I129-J81-L83-M5-M10-M12-O15 ID:261 K:336

ISSN Print: 2146-8508 Online 2147-1711

(ISO 9001-2008 Belge No / Document No: 12879 \& ISO 14001-2004 Belge No / Document No: 12880)

(MARKA PATENT NO: TRADEMARK)

(2015/04315- 2015-GE-18972)

support seeking (41-50 age group has the highest average), Avoidance (41-50 age group has the highest average), Somatization (30 and below has the highest average), Interpersonal sensitivity (51 and above has the highest average), Anxiety (30 and below has the highest average), and Phobic anxiety (41-50 age group has the highest average) vary by the age of parents.

Table 8. Jonckheere-Terpstra Test on the Methods of Coping with Stress Used by Parents by the Variable of the Age of Parents

Jonckheere-Terpstra Test ${ }^{\mathrm{a}}$

\begin{tabular}{|c|c|c|c|c|c|c|c|}
\hline & $\begin{array}{l}\text { Number of } \\
\text { Levels in the } \\
\text { Age group }\end{array}$ & $\mathrm{N}$ & $\begin{array}{l}\text { Observed } \\
\text { J-T Statistic }\end{array}$ & $\begin{array}{c}\text { Mean J-T } \\
\text { Statistic }\end{array}$ & $\begin{array}{c}\text { Std. } \\
\text { Deviation of } \\
\text { J-T Statistic }\end{array}$ & $\begin{array}{l}\text { Std. J-T } \\
\text { Statistic }\end{array}$ & $\begin{array}{l}\text { Asymp. Sig. } \\
\text { (2-tailed) }\end{array}$ \\
\hline Problem solving & 4 & 872 & 114631,000 & 123653,500 & 3981,333 & $-2,266$ &, 023 \\
\hline $\begin{array}{l}\text { Social support } \\
\text { seeking }\end{array}$ & 4 & 872 & 109776,500 & 123653,500 & 3981,799 & $-3,485$ &, 000 \\
\hline Avoidance & 4 & 872 & 103498,500 & 123653,500 & 3980,226 & $-5,064$ &, 000 \\
\hline Somatization & 4 & 872 & 134238,500 & 123653,500 & 3979,136 & 2,660 &, 008 \\
\hline $\begin{array}{l}\text { Obsessive- } \\
\text { compulsive }\end{array}$ & 4 & 872 & 129013,000 & 123653,500 & 3975,344 & 1,348 &, 178 \\
\hline $\begin{array}{l}\text { Interpersonal } \\
\text { sensitivity }\end{array}$ & 4 & 872 & 135258,500 & 123653,500 & 3981,126 & 2,915 &, 004 \\
\hline Depression & 4 & 872 & 121764,000 & 123653,500 & 3977,922 &,- 475 & ,635 \\
\hline Anxiety & 4 & 872 & 113891,500 & 123653,500 & 3982,090 & $-2,451$ &, 014 \\
\hline Hostility & 4 & 872 & 127573,000 & 123653,500 & 3971,575 & ,987 &, 324 \\
\hline Phobic anxiety & 4 & 872 & 111926,500 & 123653,500 & 3960,851 & $-2,961$ &, 003 \\
\hline Paranoid ideation & 4 & 872 & 126994,000 & 123653,500 & 3876,887 &, 862 & ,389 \\
\hline Psychoticism & 4 & 872 & 130586,500 & 123653,500 & 3968,382 & 1,747 &, 081 \\
\hline Additional scale & 4 & 872 & 123292,500 & 123653,500 & 3943,458 &,- 092 &, 927 \\
\hline
\end{tabular}

a. Grouping Variable: Age group

H6: Do the psychological wellbeing and strategies of coping with stress of parents having children with special needs vary by the education level of the parents (by the educational statuses of the mother and father)?
An examination of the methods of coping with stress used by the participating parents by the education level of parents shows that the items of Problem solving (master's degree and above has the highest average), Social support seeking (literate has the highest average), Avoidance (literate has the highest average), Somatization (literate 


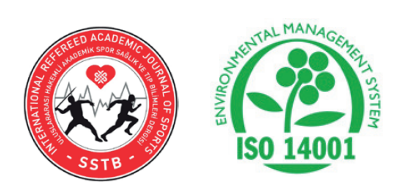

SSTB

www.sstbdergisi.com

Uluslararası Hakemli Akademik Spor Sağık Ve Tıp Bilimleri Dergisi

Ekim / Kasım / Aralık - Sonbahar Kıș Dönemi Sayı: 17 Yıl:2015

International Refereed Academic Journal of Sports, Health and Medical Sciences

October / November / December - Autumn Winter Term Issue: 17 Year: 2015

GEL CODE: D23-I12-I129-J81-L83-M5-M10-M12-O15 ID:261 K:336

ISSN Print: 2146-8508 Online 2147-1711

(ISO 9001-2008 Belge No / Document No: 12879 \& ISO 14001-2004 Belge No / Document No: 12880)

(MARKA PATENT NO: TRADEMARK)

(2015/04315- 2015-GE-18972)

has the highest average), Obsessive-compulsive (university graduate has the highest average), Interpersonal sensitivity (university graduate has the highest average), Depression (university graduate has the highest average), Anxiety (high school has the highest average), Hostility (high school has the highest average), Phobic anxiety (master's degree and above has the highest average), Paranoid ideation (middle school has the highest average), Psychoticism (high school has the highest average), and Additional scale (university graduate has the highest average) vary by the educational level of parents.

Table 9. Kruskal-Wallis Test on the Methods of Coping with Stress Used by Parents by the Variable of the Educational Level of Parents

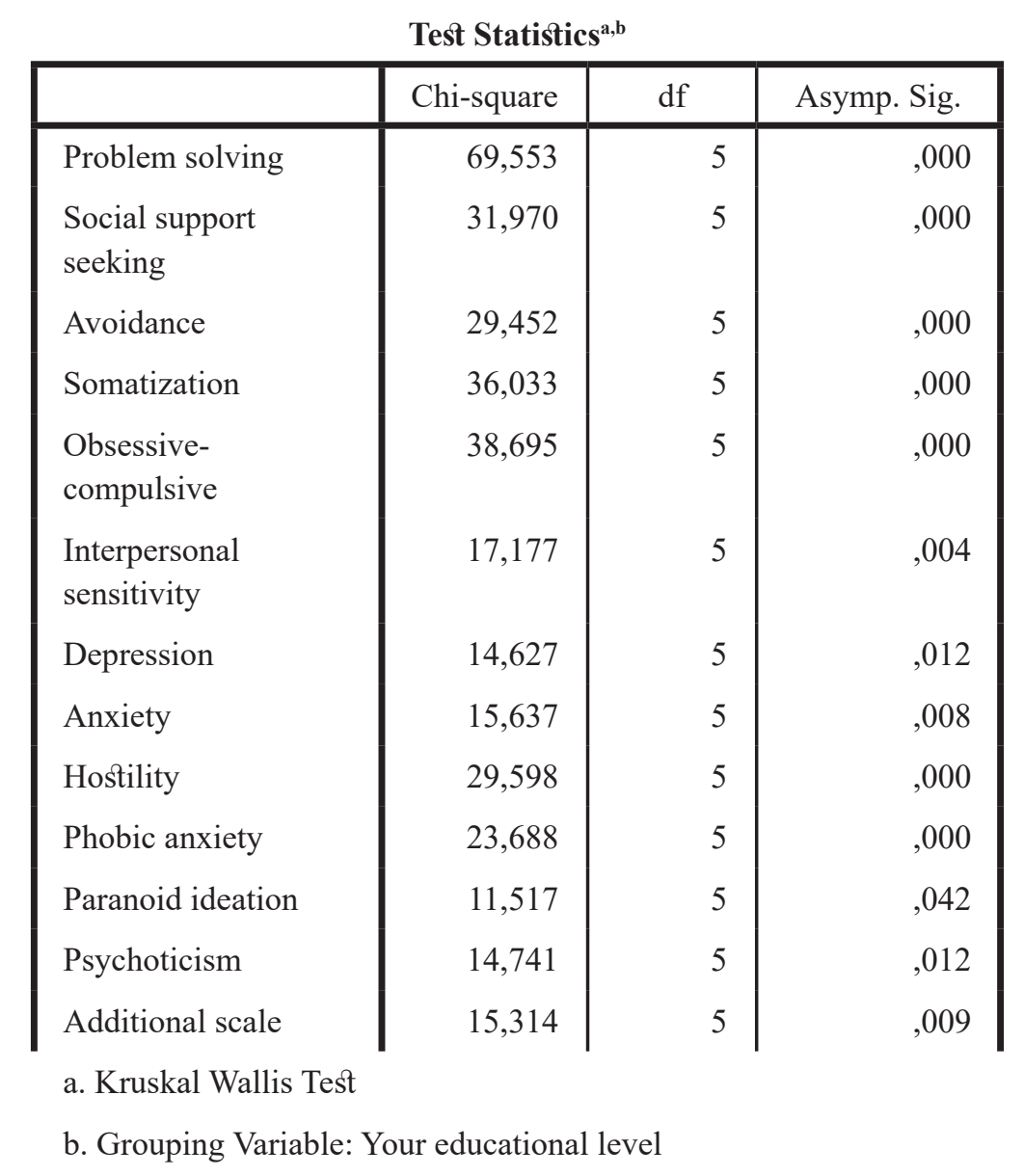

H7: Do the psychological wellbeing and strategies of coping with stress of parents having children with special needs vary by the socioeconomic level of the parents? 

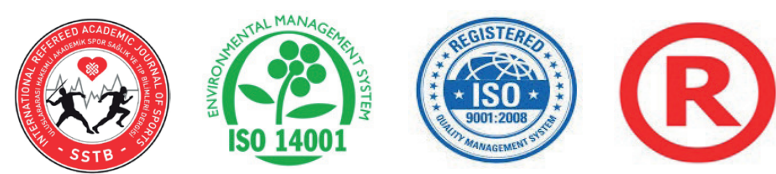

SSTB

www.sstbdergisi.com

Uluslararası Hakemli Akademik Spor Sağlık Ve Tıp Bilimleri Dergisi

Ekim / Kasım / Aralık - Sonbahar Kıș Dönemi Sayı: 17 Yıl:2015

International Refereed Academic Journal of Sports, Health and Medical Sciences

October / November / December - Autumn Winter Term Issue: 17 Year: 2015

GEL CODE: D23-I12-I129-J81-L83-M5-M10-M12-O15 ID:261 K:336

ISSN Print: 2146-8508 Online 2147-1711

(ISO 9001-2008 Belge No / Document No: 12879 \& ISO 14001-2004 Belge No / Document No: 12880)

(MARKA PATENT NO: TRADEMARK)

(2015/04315- 2015-GE-18972)

An examination of the methods of coping with stress used by the participating parents by the socioeconomic levels of parents shows that the items of Problem solving (1000-1500 TRY has the highest average), Avoidance (2001-3000 TRY has the highest average), Somatization (30014000 TRY has the highest average), Obsessivecompulsive (2001-3000 TRY has the highest average), Interpersonal sensitivity (Less than 1000 TRY has the highest average), Depression
(1000-1500 TRY has the highest average), Anxiety (1501-2000 TRY has the highest average), Hostility (3001-4000 TRY has the highest average), Phobic anxiety (More than 4000 TRY has the highest average), Paranoid ideation (3001-4000 TRY has the highest average), Psychoticism (1000-1500 TRY has the highest average), and Additional scale (2001-3000 TRY has the highest average) vary by the socioeconomic levels of parents.

Table 10. Jonckheere-Terpstra Test on the Methods of Coping with Stress Used by Parents by the Variable of the Socioeconomic Status of Parents

\begin{tabular}{|c|c|c|c|c|c|c|c|}
\hline \multicolumn{8}{|c|}{ Jonckheere-Terpstra Test ${ }^{\mathrm{a}}$} \\
\hline & $\begin{array}{l}\text { Number of } \\
\text { Levels in Your } \\
\text { monthly income }\end{array}$ & $\mathrm{N}$ & $\begin{array}{c}\text { Observed J-T } \\
\text { Statistic }\end{array}$ & $\begin{array}{c}\text { Mean J-T } \\
\text { Statistic }\end{array}$ & $\begin{array}{l}\text { Std. Deviation } \\
\text { of J-T Statistic }\end{array}$ & $\begin{array}{l}\text { Std. J-T } \\
\text { Statistic }\end{array}$ & $\begin{array}{l}\text { Asymp. } \\
\text { Sig. } \\
\text { (2-tailed) }\end{array}$ \\
\hline Problem solving & 6 & 872 & 174515,500 & 155795,000 & 4213,957 & 4,442 & 000 \\
\hline Social support seeking & 6 & 872 & 153774,000 & 155795,000 & 4214,454 &,- 480 & ,632 \\
\hline Avoidance & 6 & 872 & 135177,500 & 155795,000 & 4212,783 & $-4,894$ &, 000 \\
\hline Somatization & 6 & 872 & 132921,000 & 155795,000 & 4211,625 & $-5,431$ &, 000 \\
\hline Obsessive-compulsive & 6 & 872 & 124035,500 & 155795,000 & 4207,597 & $-7,548$ &, 000 \\
\hline Interpersonal sensitivity & 6 & 872 & 140709,500 & 155795,000 & 4213,735 & $-3,580$ &, 000 \\
\hline Depression & 6 & 872 & 128320,500 & 155795,000 & 4210,333 & $-6,525$ & 000 \\
\hline Anxiety & 6 & 872 & 132534,500 & 155795,000 & 4214,762 & $-5,519$ &, 000 \\
\hline Hostility & 6 & 872 & 130203,000 & 155795,000 & 4203,604 & $-6,088$ &, 000 \\
\hline Phobic anxiety & 6 & 872 & 144349,000 & 155795,000 & 4192,234 & $-2,730$ &, 006 \\
\hline Paranoid ideation & 6 & 872 & 133902,000 & 155795,000 & 4103,309 & $-5,335$ &, 000 \\
\hline Psychoticism & 6 & 872 & 141333,000 & 155795,000 & 4200,213 & $-3,443$ &, 001 \\
\hline Additional scale & 6 & 872 & 141114,500 & 155795,000 & 4173,808 & $-3,517$ &, 000 \\
\hline
\end{tabular}

a. Grouping Variable: Your monthly income 


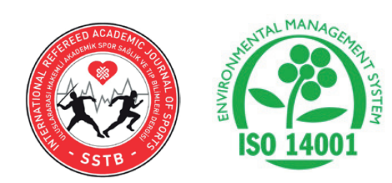

SSTB

www.sstbdergisi.com

Uluslararası Hakemli Akademik Spor Sağlık Ve Tıp Bilimleri Dergisi

Ekim / Kasım / Aralık - Sonbahar Kış Dönemi Sayı: 17 Yıl:2015

International Refereed Academic Journal of Sports, Health and Medical Sciences

October / November / December - Autumn Winter Term Issue: 17 Year: 2015

GEL CODE: D23-I12-I129-J81-L83-M5-M10-M12-O15 ID:261 K:336

ISSN Print: 2146-8508 Online 2147-1711

(ISO 9001-2008 Belge No / Document No: 12879 \& ISO 14001-2004 Belge No / Document No: 12880)

(MARKA PATENT NO: TRADEMARK)

(2015/04315- 2015-GE-18972)

\section{CONCLUSION and ASSESSMENT}

- An examination of the methods of coping with stress used by the participating parents shows that the items of Problem solving (7-9 age group has the highest average), Social support seeking (10-12 age group has the highest average), Somatization (13-17 age group has the highest average), Obsessivecompulsive (13-17 age group has the highest average), Interpersonal sensitivity (13-17 age group has the highest average), Hostility (13-17 age group has the highest average), Phobic anxiety (7-9 age group has the highest average), Paranoid ideation (10-12 age group has the highest average), Psychoticism (1012 age group has the highest average), and Additional scale (13-17 age group has the highest average) vary by the age of child.

- An examination of the methods of coping with stress used by the participating parents by the gender of their children shows that the items of Problem solving (Females have the highest average), Social support seeking (Females have the highest average), Somatization (Males have the highest average), Depression (Females have the highest average), and Hostility (Males have the highest average) are affected by the gender of the child while the others are not affected.

- An examination of the methods of coping with stress used by the participating parents by the type of disability shows that the items of Problem solving (visual impairment has the highest average), Social support seeking (hearing impairment has the highest average), Avoidance (visual impairment has the highest average), Somatization (visual impairment has the highest average), Obsessive-compulsive (mental disability has the highest average), Interpersonal sensitivity (visual impairment has the highest average), Anxiety (visual impairment has the highest average), Phobic anxiety (mental disability has the highest average), and Additional scale (visual impairment has the highest average) are affected by the child's type of disability.

- An examination of the methods of coping with stress used by the participating parents by the gender of the parents shows that the items of Problem solving (female has the highest average), Social support seeking (female has the highest average), Avoidance (female has the highest average), Somatization (female has the highest average), Obsessivecompulsive (female has the highest average), Interpersonal sensitivity (female has the highest average), Depression (female has the highest average), Anxiety (female has the highest average), Hostility (female has the highest average), Phobic anxiety (female has the highest average), Paranoid ideation (female has the highest average), Psychoticism (female has the highest average), and Additional scale 


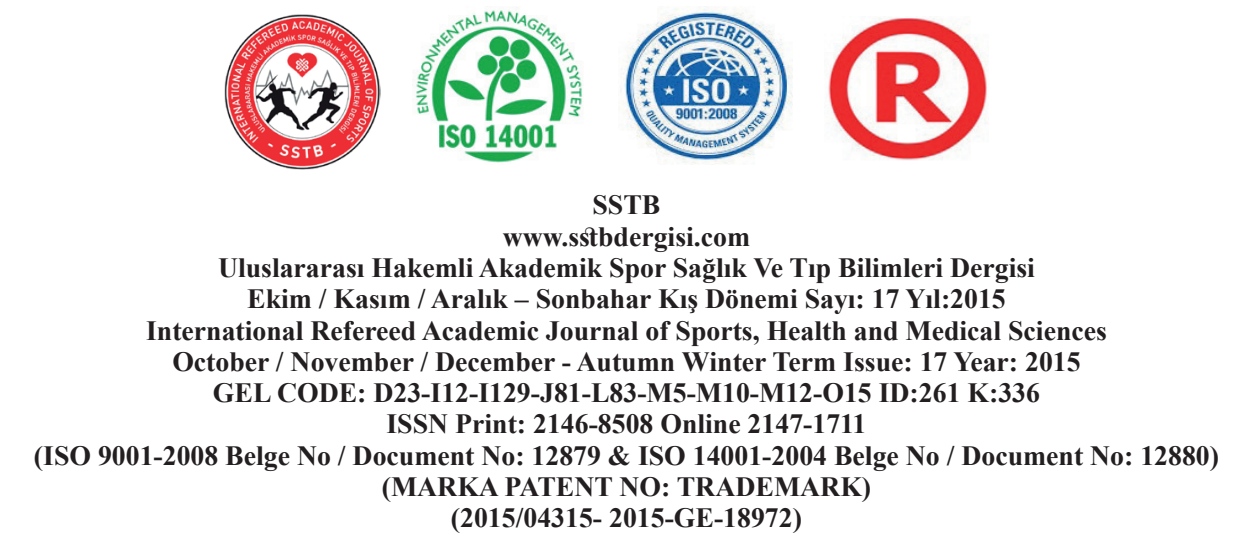

(female has the highest average) vary by the gender of the parent.

- An examination of the methods of coping with stress used by the participating parents by the age of parents show that the items of Problem solving (31-40 age group has the highest average), Social support seeking (41-50 age group has the highest average), Avoidance (41-50 age group has the highest average), Somatization (30 and below has the highest average), Interpersonal sensitivity (51 and above has the highest average), Anxiety (30 and below has the highest average), and Phobic anxiety (41-50 age group has the highest average) vary by the age of parents.

- An examination of the methods of coping with stress used by the participating parents by the education level of parents shows that the items of Problem solving (master's degree and above has the highest average), Social support seeking (literate has the highest average), Avoidance (literate has the highest average), Somatization (literate has the highest average), Obsessive-compulsive (university graduate has the highest average), Interpersonal sensitivity (university graduate has the highest average), Depression (university graduate has the highest average), Anxiety (high school has the highest average), Hostility (high school has the highest average), Phobic anxiety (master's degree and above has the highest average), Paranoid ideation (middle school has the highest average), Psychoticism (high school has the highest average), and Additional scale (university graduate has the highest average) vary by the educational level of parents.

- An examination of the methods of coping with stress used by the participating parents by the socioeconomic levels of parents shows that the items of Problem solving (1000-1500 TRY has the highest average), Avoidance (2001-3000 TRY has the highest average), Somatization (3001-4000 TRY has the highest average), Obsessive-compulsive (2001-3000 TRY has the highest average), Interpersonal sensitivity (Less than 1000 TRY has the highest average), Depression (1000-1500 TRY has the highest average), Anxiety (1501-2000 TRY has the highest average), Hostility (3001-4000 TRY has the highest average), Phobic anxiety (More than 4000 TRY has the highest average), Paranoid ideation (3001-4000 TRY has the highest average), Psychoticism (1000-1500 TRY has the highest average), and Additional scale (2001-3000 TRY has the highest average) vary by the socioeconomic levels of parents.

\section{REFERENCES}

AKÇAKIN, M., ERDEN, G., (2001). Otizm tanısı konmuş çocukların anne- babalarındaki ruhsal belirtiler. Çocuk Ruh Sağllğg Journal, 8(1), 2-10 


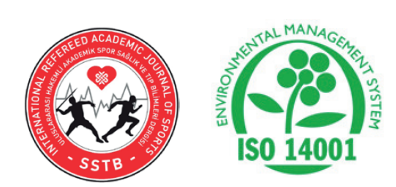

SSTB

www.sstbdergisi.com

Uluslararası Hakemli Akademik Spor Sağlık Ve Tıp Bilimleri Dergisi

Ekim / Kasım / Aralık - Sonbahar Kıș Dönemi Sayı: 17 Yıl:2015

International Refereed Academic Journal of Sports, Health and Medical Sciences

October / November / December - Autumn Winter Term Issue: 17 Year: 2015

GEL CODE: D23-I12-I129-J81-L83-M5-M10-M12-O15 ID:261 K:336 ISSN Print: 2146-8508 Online 2147-1711

(ISO 9001-2008 Belge No / Document No: 12879 \& ISO 14001-2004 Belge No / Document No: 12880)

(MARKA PATENT NO: TRADEMARK)

(2015/04315- 2015-GE-18972)

AKCAMETE, G., KARGIN, T., (1996). İşitme engelli çocuğa sahip annelerin gereksinimlerinin belirlenmesi. Özel Eğitim Journal, 2(2), 7-24

AKKOK, F., (1989). Özürlü bir çocuğa sahip anne ve babaların anxiety ve endişe düzeyini ölçme aracının güvenirlik ve geçerlik çalışması. Psikoloji Journal, 7(23),26-38

\section{AKKOK, F, AŞKAR, P., and KARANCI, N., (1992).}

Özürlü bir çocuğa sahip anne-babalardaki stresin yordanması. Özel Eğitim Journal, $1(2), 8-13$

ASLAN, C., (2010). Zihinsel engelli çocuğu olan anne-babalarm psikolojik belirtileri, sosyal destek algıları ve stresle başa çıkma tarzlarının karşılaştırılması. Unpublished Master's Thesis. Maltepe University, İstanbul

ASLANOĞLU, M., (2004). Otistik, zihinsel, işitme, görme ve bedensel engelli çocuğu bulunan ebeveynlerin aile içi ilişkilerinin incelenmesi. Unpublished Master's Thesis, Dokuz Eylül University, İzmir

ATAMAN, A., (2003). Özel ĕgitime muhtaç olmanin nedenleri. (ed. A. Ataman). Özel Eğitime Giriş. Gündüz Eğitim Yayıncılık. Ankara

AYDOĞAN, A.A., (1999). Özürlü çocuğa sahip olan anne babaların umutsuzluk düzeylerinin belirlenmesi. Unpublished PhD Thesis, Hacettepe University, Ankara
BAILEY, D.B., and SIMENSON, R.J., (1988).

Assessing needs of families handicapped infants. The Journal of Special Education, 22(1), 117-127

BAYRAM, N., (2009). Sosyal bilimlerde SPSS ile veri analizi. (2nd Edition). Ezgi Yayınevi. Bursa

BECKMAN, J.P., (1983). Influence of selected child characteristics on stress in families of handicapped infants American Journal of Mental Deficiency, 88(2), 150-156

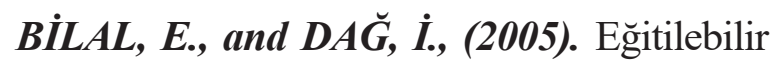
zihinsel engelli olan ve olmayan çocukların annelerinde stresi stresle başa çıkma ve kontrol odağının karşılaştırılması. Çocuk ve Gençlik Ruh Sağlı̆̆ı Journal, 12(2),56-68

BRASSARD, M.R., and BOEHM, A.E., (2008). Preschool assessment: Principles and practice. New York, NY: The Guilford Pres

B̈̈YÜKBOZKURT, Ş., (2008). Sosyal bilimler için veri analizi el kitabl. (9th Edition). Pegem Akademi, Ankara

COŞKUN, Y., and $A K K A S ̧$, G., (2009). Engelli çocuğu olan annelerin sürekli anxiety düzeyleri ile sosyal destek algıları Arasındaki ilişki. Ahi Evran University Kırşehir Faculty of Education Journal (KEFAD), 10(1), 213-227 


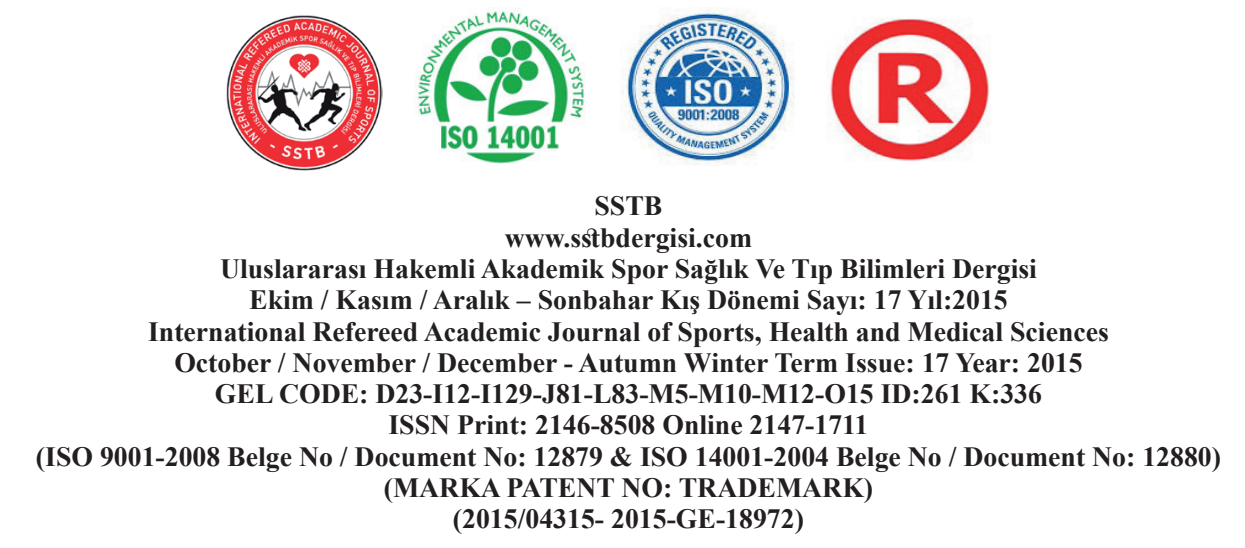

ÇELIK, D., (2004). İşitme engelli çocuğa sahip olmanin aile işlevlerine etkisi. Unpublished Master's Thesis, Hacettepe University, Ankara

DOĞAN, M., (2001). İşitme engelli çocuğa sahip ebeveynlerin çeşitli psikolojik değişkenler açısından değerlendirilmesi. Unpublished Master's Thesis, Ankara University, Ankara

DOĞRU, P., and ARSLAN, A., (2008). Engelli çocuğu olan annelerin sürekli anxiety düzeyi ile durumluk anxiety düzeylerinin karşılaştırılması. Selçuk University, Institute of Social Sciences Journal, 19,543-553

DYSON, L.L., (1997). Fathers and mothers of school- age children with developmental disabilities: Parental stress, family functioning, and social support. American Journal on Mental Retardation, 102(3),267-279

\section{ESDAILE, S.A., and GREENWOOD, K.M.,} (2003). A comparison of mothers and fathers experience of parenting stres and attiributions for parent child intreaction outcomes. Occup. Ther. Int., 10-115-126

FLOYD, F.J., and GALLAGHER, E.M., (1997). Parental stress, care demands, and use of support services for school age children with disabilities and behavior problems. Family Relations, 46(4),359-372

GALLAGHER, J.J., BECKMAN, P., and CROSS, A.H., (1983). Families of handicapped children: Sources of stress and its amelioration. Exceptional Children, 50(1),10-19

GíRLI, A., (1995). Normal zekâlı kardeşlerin zihinsel engelli kardeşe yönelik kabul düzeyinin belirlenmesi. Unpublished Master's Thesis, Dokuz Eylül University, İzmir

GLIDDEN, L.M., and SCHOOLCRAFT, S. $A$., (2003). Depression: It's trajection and correlates in mothers rearing children with intellectual disability. Journal Intellect Disabil, Res., 47,250,263

GÜNSEN, A.G., (2010). Zihinsel engelli tanısı almış çocuğa sahip ailelerin aile işlevlerinin bazı değişkenler Açısından incelenmesi. Unpublished Master's Thesis, Ege University, İzmir

GÜZ, F, ŞENSES, M., KARAKUZU, A., and ATEŞ, N., (1998). Zihinsel özürlü çocuk ailelerinin evde bakım ile ilgili Sorunlarının belirlenmesi. 1. Ulusal Evde bakım Eğitim Kongresi Kitabl. Marmara University Basımevi, İstanbul

HASSAL, R., ROSE, J., and McDONALD, $J$. , (2005). Parenting stress in mothers and children with an intellectual disability: the effects of parental cognitions in relation to child characteristics and family support. Journal of Intellectual Disability Research, 49(6), 405-418 


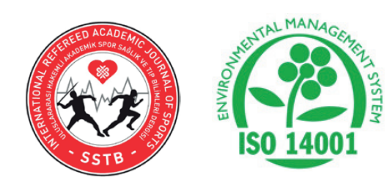

SSTB

www.sstbdergisi.com

Uluslararası Hakemli Akademik Spor Sağlık Ve Tıp Bilimleri Dergisi

Ekim / Kasım / Aralık - Sonbahar Kıș Dönemi Sayı: 17 Yıl:2015

International Refereed Academic Journal of Sports, Health and Medical Sciences

October / November / December - Autumn Winter Term Issue: 17 Year: 2015

GEL CODE: D23-I12-I129-J81-L83-M5-M10-M12-O15 ID:261 K:336

ISSN Print: 2146-8508 Online 2147-1711

(ISO 9001-2008 Belge No / Document No: 12879 \& ISO 14001-2004 Belge No / Document No: 12880)

(MARKA PATENT NO: TRADEMARK)

(2015/04315- 2015-GE-18972)

HASTINGS, R.P., (2003). Child behavior problems and partner mental health as correlates of stress in mothers and fathers of children with autism. Journal Intellect Disabil Res, $47,231-237$

KANER, S., (2002). Aile stres değerlendirme ölçeği faktör yapısı, güvenirlik ve geçerlik çalışmaları. Ankara University Educational Sciences Journal, 34(1-2),1-10

KANER, S., (2004). Engeli çocukları olan annebabalarin algiladiklart stres, sosyal destek ve yaşam doyumlarinin Incelenmesi. (Bilimsel Araştırma Projesi: 007)Ankara University.

KAVAK, S., (2007). Algilanan aile yaktnları destek ölçeğinin geliştirilmesi ve 0-6 yaş arası engelli çocuğu olan Annelerin yakinlarından aldı̆̆ desteği algılamaları. Unpublished Master's Thesis, Marmara University, İstanbul

KAZAK, A.E., (1987). Families with disabled children stress and social Networks in three samples. Journal of Abnormal Child Psychology, 15(1), 137-146

KIĞILI, Ş., (1994). Anne baba ve çocuğun kendi aile yapılarına ilişkin değerlendirmelerinin bazı değişkenlere göre Incelenmesi. Unpublished Master's Thesis, İnönü University, Malatya

KRAUSS, M.W., (2000). Family assessment with early intervention program. In: Shonkoff, J.P.\&Meisels, S.J. (Eds.) Handbook of early childhood intervention (2nd ed.). New York, NY: Cambridge University Press, 290-308

KÜÇÜKER, S., (2001). Erken eğitimin gelişimsel geriliği olan çocukların anne-babalarının stres ve depression düzeyleri üzerindeki etkisinin incelenmesi. Özel Eğitim Journal, 3(1),1-11

KULLU,Z., (2008). Özürlü çocuğa sahip ebeveynlerin depression durumunun değerlendirilmesi. Unpublished Master's Thesis, Erciyes University, Kayseri

KORKMAZ, M., et all., (2014). "7-17 Yaş Arası Farklı Gelişimsel Özellikleri Olan Çocuklara Sahip Ailelerin Stresle Başa Çıkma Yöntemlerinin İncelenmesi” ACED International Journal of Family, Child and Education, August-December No:04, Volume: 02 pp. $16-50$

LUSTING, D., (1999). Family care giving of adults with mental retardation: Key issues for rehabilitation. The Journal of Rehabilitation, $1,20-40$

MARCENKO, M.O., and MEYERS, J.C., (1991). Mothers of children with developmental disabilities: Who share the Burden? Family Relations, 40-186-190

MARSH, D.T., (1992). Families and mental retardation: New directions in Professional practice. New York, NY: Greenwood Publishing Group 


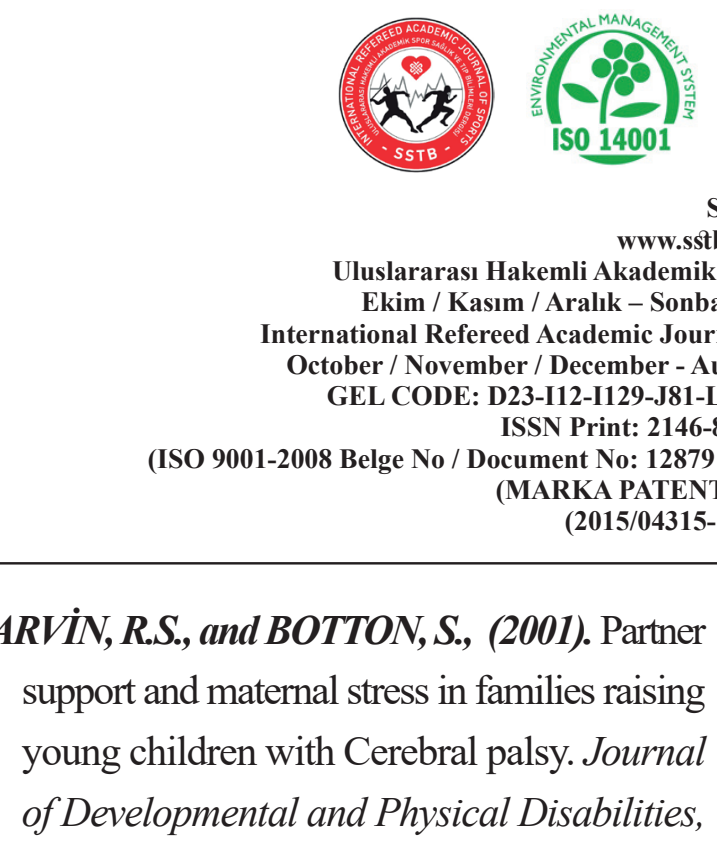$$
\text { www.sstbdergisi.com }
$$$$
\text { Uluslararası Hakemli Akademik Spor Sağlık Ve Tıp Bilimleri Dergisi }
$$$$
\text { Ekim / Kasım / Aralık - Sonbahar Kış Dönemi Sayı: } 17 \text { Yıl:2015 }
$$$$
\text { International Refereed Academic Journal of Sports, Health and Medical Sciences }
$$$$
\text { October / November / December - Autumn Winter Term Issue: } 17 \text { Year: } 2015
$$$$
\text { GEL CODE: D23-I12-I129-J81-L83-M5-M10-M12-O15 ID:261 K:336 }
$$$$
\text { ISSN Print: 2146-8508 Online 2147-1711 }
$$

(ISO 9001-2008 Belge No / Document No: 12879 \& ISO 14001-2004 Belge No / Document No: 12880) (MARKA PATENT NO: TRADEMARK) (2015/04315- 2015-GE-18972)
MARVIN, R.S., and BOTTON, S., (2001). Partner 13(1), 61-64

MERT, E., (1997). Farklı engel grubunda çocuğu olan anne ve babalarin gereksinimlerinin karşılaştırılması. Unpublished Master's Thesis, Abant İzzet Baysal University, Bolu

OH, H., and LEE, E.O., (2009). Care giver burden and social support among mothers raising children with developmental disabilities in South Korea. International Journal of Disability, Development and Education, 56(2), 149-167

OKANLI, A., et all., (2004). Zihinsel engelli çocuğa sahip ailelerin yaşadikları psikososyal sorunlar. www.insanbilimleri.com Accessed: 11.06.2015

ORR, R.R., et all., (1993). Age-related changes in stress experienced by families with a child who has developmental delays. Mental Retardation, 31(3),171-176

ÖZGÜVEN, İ.E., (2000). Evlilik ve Aile Terapisi. PDREM Yayınları, Ankara

OZSOY, Y., et all., (1998). Özel eğitime giriş. (9th Edition). Kocatepe Yayınları, Ankara

OZSOY, A.S., ve diğ., (2006). Zihinsel engelli çocuk sahibi ailelerin yaşadıkları güçlüklerin
İncelenmesi. Aile ve Toplum Eğitim, Kültür ve Araştırma Journal, 3(9), 68-76

OZŞENOL, F., et all. (2003). Engelli çocuğa sahip ailelerin aile işlevlerinin değerlendirilmesi. Gülhane Tip Journal, 45(2),156-164

OZYURT, O., (2011). Hafif zihinsel engelli çocuğu olan annelerin algıladıkları aile işleyişi ve aile yaşam kalitesinin sosyodemografik değisskenler açısından incelenmesi. Unpublished Master's Thesis, Maltepe University, İstanbul

PISTTON, A., et all., (2007). Serebral paralizili çocukların annelerinin anxiety düzeyinin Araştırılması. Ankara Çocuk Sağlığı ve Hastalıkları Journal, 50(4),236-240

SARI, Y.H., (2007). Zihinsel engelli çocuğu olan ailelerde aile yüklenmesi. Cumhuriyet University School of Nursing Journal, 11(2),1-7

SARISOY, M., (2000). Otistik ve zihinsel engelli çocuğa sahip olan ebeveynlerin evlilik uyumları. Unpublished Master's Thesis, Ege University, İzmir

SEXTON, D., et all., (1992). Measurement integrity of the family need survey. Journal of Early Intervention, 16(4),343-352

SEVINDIK, F., et all., (2006). Engelli çocuğu olan kadınların demografik, psikososyal ve engelli çocuğa ait doğumsal özelliklerinin incelenmesi. Sağllk ve Toplum Journal, $16(3), 38-47$ 


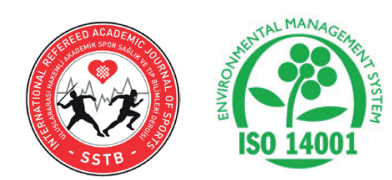

SSTB

www.sstbdergisi.com

Uluslararası Hakemli Akademik Spor Sağlık Ve Tıp Bilimleri Dergisi

Ekim / Kasım / Aralık - Sonbahar Kıș Dönemi Sayı: 17 Yıl:2015

International Refereed Academic Journal of Sports, Health and Medical Sciences

October / November / December - Autumn Winter Term Issue: 17 Year: 2015

GEL CODE: D23-I12-I129-J81-L83-M5-M10-M12-O15 ID:261 K:336

ISSN Print: 2146-8508 Online 2147-1711

(ISO 9001-2008 Belge No / Document No: 12879 \& ISO 14001-2004 Belge No / Document No: 12880)

(MARKA PATENT NO: TRADEMARK)

(2015/04315- 2015-GE-18972)

SIMMERMAN, S., et all., (2001). Fathers and mothers perceptions of father involvement in families with young children with a disability. Journal of Intellectual Developmental Disability,26(4),325-338

SOLA, C., and DIKKEN, H., (2008). Gelişimsel gerilik riski altındaki premature ve düşük doğum ağırlıklı çocuğa sahip Annelerin gereksinimlerinin belirlenmesi. Ankara University Faculty of Educational Sciences Özel Eğitim Journal, 9(2),21-36

SUCUOĞLU, B., (1995). Özürlü çocuğu olan anne-babalarn gereksinimlerinin belirlenmesi. Çocuk ve Gençlik Journal, 2(1), 10-18

Torster, H. (2001). Sources of stress in mothers of young children with visual impairment. Journal of Visual Impairment and Blindness, 95(10), 623-637

O $\breve{G} U \boldsymbol{Z}$, Ş., et all., (2004). Zihinsel ve/veya bedensel engelli çocukların Annelerinin anksiyete, depression ve stres düzeylerinin belirlenmesi. Klinik Psikiyatri Journal, 7,42-47

ULUTAŞDEMIR, N., (2007). Engelli çocukların eğitimi. Firat Sağllk Hizmetleri Journal, 2(5),119-130

UŞKAN E., et all., (2005). Isparta ilinde özürlülük, sakatlık ve engellilik epidemiyolojisi: Sağglk ve Toplum Journal, 15(1),90-99
WALLENDER, J.L., et all., (1989). Social environment and the Adaptation of mothers of physically handicapped children. Journal of Pediatric Psyhology, 14,371-378

WILTON, K., and RENAULT, J., (1986).

Stress level in families with intellectually handicapped preschool children. Journal of Mentally Defiency Research, 30,163-169

YILDIRIM, F., and CONK, Z., (2005). Zihinsel yetersizliği olan cocuğa sahip anne babaların stresle başa cıkma tarzlarına ve depression düzeylerine planlı eğitime etkisi. Cumhuriyet University School of Nursing Journal, 9(2),1-10

\section{INTERNET RESOURCES}

http://www.ataturkuni.net/ow userfiles/plugins/ forum/attachment_2839_54c8fda7ba161_5 4c8fc5e47530\%C3\%BCnite-5toplumsalbir-krum-olarak-evlilik-ve-aile.pdf Accessed: 16.05.2015

http://www.canaktan.org/politika/refah-devleti/ araclar.htm Accessed: 11.06.2015

https://www.academia.edu/5811043/A\%C4\%B0LE

NED $\% \mathrm{C} 4 \% \mathrm{~B} 0 \mathrm{R} \quad \mathrm{A} \% \mathrm{C} 4 \% \mathrm{~B} 0 \mathrm{LE} \% \mathrm{C} 3 \%$ 87E $\%$ C $5 \% 9 \mathrm{E} \% \mathrm{C} 4 \% \mathrm{~B} 0 \mathrm{TLER} \% \mathrm{C} 4 \% \mathrm{~B} 0$

Accessed: 11.06.2015

http://tegm.meb.gov.tr/dosya/okuloncesi/036ebaderegitimcikitap.pdfAccessed: 16.05.2015 